\title{
Transformation Digital of Zakat Institutions During Covid-19 Pandemic In The Kalimantan Region
}

\author{
Nurul Fadhilah ${ }^{1 *}$ \\ ${ }^{1}$ Faculty of Islamic Economic and Business, Sultan Aji Muhammad Idris Islamic University, \\ Samarinda, Indonesia
}

\begin{abstract}
This research was motivated by the covid pandemic which not only had an impact on the economic sector but also had an impact on people's behavior. In terms of behavior, it is the tendency of people to carry out non-cash transactions, including in terms of zakat management. Zakat with cashless can be applied by building the digitization of zakat. Digital transformation needs to be done, in order to be able to optimize the potential of zakat in Kalimantan. This study aims to determine the extent to which zakat institutions have started digital transformation, especially during the COVID-19 pandemic and to determine the digital management gap between zakat institutions in the Kalimantan Region. This type of research is descriptive quantitative research. The object of research is zakat institutions in Kalimantan. Sample collection method using cluster sampling. Research data in the form of primary data collected through questionnaires. Researchers found that in general zakat institutions have implemented the digitization of zakat management. South Kalimantan applies the best digital management, while the largest digital divide is North Kalimantan.
\end{abstract}

\section{Introduction}

The COVID-19 pandemic has not only had an impact on the global health sector, but also on the economic sector, and on people's behavior. From the health sector, the Corona virus is prone to causing death (Robin, 2021; Tiwari et al., 2020). From an economic perspective, the sectors affected by the COVID-19 pandemic are transportation, tourism, trade, health, and the household sector most affected by COVID-19(Abodunrin et al., 2020 ; Susilawati et al., 2020). Many companies close their businesses and lay off their employees (Bartik et al., 2020 ; Putri et al., 2021). In terms of behavior change, there is a tendency for people to transact non-cash using digital wallets or e-wallets in order to reduce the risk of being infected with the corona virus attached to money (Katon \& Yuniati, 2020; Krismawintari et al., 2020)

Given the importance of zakat distribution as one of the solutions in overcoming the crisis during the pandemic (Fadhilah, 2020), the distribution of zakat with the cashless concept can be applied if zakat institutions build zakat digitization (Aini et al., 2018). Digitization of zakat

* Corresponding author: nurul.fadhilah@iain-samarinda.ac.id 


\section{$A \mathrm{I} \overline{I E B}$ Annual International Conference \\ on Islamic Economics and Business, 2021}

can be applied by developing the digitization of zakat collection, zakat management, and zakat distribution (Zubaidah \& Afifah, 2020).

Digitization of zakat not only brings positive changes in people's lives, but also raises a new problem that is quite serious, namely the problem of the digital divide.(Van Dijk \& Hacker, 2003). This digital gap arises because of the inequality that occurs between zakat institutions and people who cannot enjoy the development of information technology (Ariyanti, 2016).

If we look further, the development of information technology is increasing day by day. Based on the results of a survey by the Central Statistics Agency published in 2021 regarding the Kalimantan Information and Communication Technology Development Index (IP-TIK), the data shows that Indonesia's Information and Communication Technology Development Index (IP-TIK) has increased. The increase in the Information and Communication Technology Development Index (IP-TIK) shows that information technology is also growing. The following is IP-TIK in Kalimantan in 2019 and 2020 (BRSbrsInd20210818114849 (1).Pdf, n.d.).

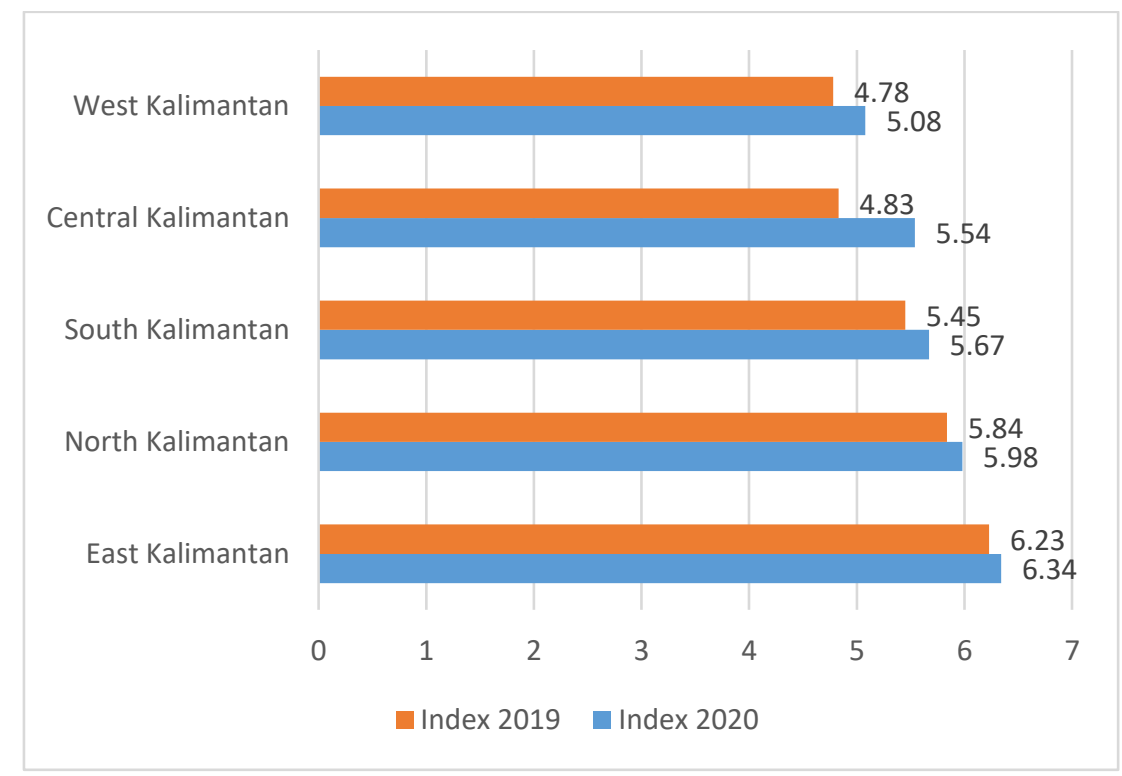

Fig. 1. ICT Development Index (IP-TIK)

From the diagram above, it is known that the position of ICT development in Kalimantan Province, the highest IP-ICT value is East Kalimantan Province with a medium category. While the lowest is West Kalimantan Province. Even so, West Kalimantan Province experienced a shift in development from the low category in 2019 to medium in 2020.

This is of course very interesting to study, considering that the development of ICT development does not necessarily indicate the development of digital transformation of zakat institutions on the island of Kalimantan. So, this research was conducted to answer the question to what extent have zakat institutions started their digital transformation during the covid-19 pandemic and how is the digital zakat management gap between zakat institutions during the covid-19 pandemic in the Kalimantan region? This research will contribute as a consideration for both zakat institutions and related government institutions to implement zakat digitization. In addition, this research can also be a reference for studying digital transformation more deeply. 


\section{$A I C \overline{C E B} \quad$ Annual International Conference \\ on Islamic Economics and Business, 2021}

\section{Literature Review}

Digital transformation is a process of utilizing existing digital technologies such as virtualization technology, mobile computing, cloud computing, integration of all existing systems in the organization and so on (S. Eaves J. Loonam et al., 2018). There are also those who interpret it as the impact obtained from the use of a combination of digital innovations that result in changes to the structure, values, processes, positions or ecosystems within the organization and the environment outside the organization (B. Hinings, et al., 2018). Digital transformation is also a concept integrating all coordination, priority, and strategy implementation in the company (Matt et al., 2015). From some of these definitions, it can be simply concluded that digital transformation is an extraordinary process where the process involves the available resources including utilizing digital technology that existed at that time to produce organizational outputs to provide new experiences. This new experience can manifest as a new value obtained by consumers such as ease of transaction, shopping, communication, and so on.

There are 4 factors driving digital transformation. These factors are 1) changes in regulation, 2) changes in the competitive landscape, 3) shifts/changes to the digital form of the industry, 4) changes in consumer behavior and expectations (K. Osmundsen et al., 2018). The current driving force for digital transformation is the COVID-19 pandemic. Everyone is asked not to meet physically but digitally, be it for work or study. So during the pandemic, the terms work and study from home are common.

The digital divide is defined as the gap between individuals, households, businesses, (or community groups) and geographic areas at different socioeconomic levels in terms of opportunities for access to information and communication technology/ICT or telematics and the use of the internet for various activities. So, the digital divide actually reflects various gaps in the use of telematics due to differences in its use within a country and/or between countries. The cause of the digital divide is due to the following factors (Ariyanti, 2016).

- Infrastructure. Infrastructure is a facility that supports smooth access to technology. Such infrastructures include electricity, internet and computers. As an example of this infrastructure gap, people who have access to computers can work faster than people who still use manual typewriters. Another example, people who have access to computers and to the internet, automatically have a broader perspective than those who do not have access to information on the wide-ranging Internet.

- Lack of skills (HR). Human resources are very influential in the world of technology and information because these human resources determine whether or not a person normally operates or accesses information.

- Lack of Indonesian language content. Indonesian language content determines whether or not someone can understand accessing the internet. In areas with people who have a higher level of education can more easily understand English content than areas with people with lower education. Therefore, the content really needs to be adapted to each region. Rural areas should be provided with more Indonesian content, so that it is easier for them to understand the content.

- Lack of use of the internet itself. Talking about the digital divide is not just an infrastructure issue. Many people who have computers, even every day, hour- can access the Internet but "do nothing". For example, suppose a teenager has access to a computer and the Internet. But all he did was chat mediocre. Of course, he could not enjoy the benefits provided by digital technology. That means, the digital divide cannot only be answered by providing infrastructure. Infrastructure is certainly needed but the problem is when people have computers and can access the Internet, the next question is, "what do you want to access? what he wants to do with the equipment, with the advantages of the technology. 


\section{$A \mathrm{IC} \quad$ Annual International Conference \\ on Islamic Economics and Business, 2021}

Basrowi concluded that the use of financial technology was able to increase the number of muzakki, increase zakat receipts, reduce risk, which in turn was able to increase the welfare of mustahik and be able to reduce the number of mustahik into muzakki (Basrowi \& Utami, 2020).

With the use of digital platforms during the covid-19 pandemic, it will make it easier to manage zakat, where there are suggestions for social distancing. Digitizing zakat will optimize the potential of zakat that has not been collected. (Utami et al., 2020) Zakat institutions can collaborate with more financial technology (fintech) companies to raise zakat funds. The convenience offered in paying zakat digitally and the rapid development of financial technology are great strengths and opportunities. On the other hand, people's lack of knowledge and skills in information technology and the emergence of cybercrime are both weaknesses and threats from the digitalization of zakat (Ninglasari \& Muhammad, 2021).

In managing zakat, innovation is needed by implementing fintech on the zakat information system(Santoso, 2019). Zubaidah and Afifah concluded that digital zakat management has many benefits, namely (1) improving the performance of zakat institutions, (2) increasing efficiency, transparency, and accountability, (3) facilitating zakat institutions to monitor zakat, (4) facilitating the realization of zakat potential. , and (5) digital zakat management as a solution during the pandemic. The development of digital zakat can be built in the following ways: (Zubaidah \& Afifah, 2020).

Table 1. Development of Zakat Digitization

\begin{tabular}{|c|c|c|}
\hline No & Development of zakat digitalization & Strategies Step \\
\hline \multirow{6}{*}{1} & \multirow{6}{*}{ Digitalization on Zakat Collection } & Developing website-based service \\
\hline & & Developing an android-based application \\
\hline & & E-Commerce \\
\hline & & E-wallet \\
\hline & & Crowdfunding \\
\hline & & Ride-Hailing \\
\hline \multirow{2}{*}{2} & \multirow{2}{*}{ Digitalization on Zakat Management } & Application-based Muzakki Service \\
\hline & & Application - Internal Platform \\
\hline 3 & $\begin{array}{l}\text { Digitalization on Zakat Funds } \\
\text { Distribution }\end{array}$ & Zakat Integrated Database System \\
\hline
\end{tabular}

Digital of zakat management has advantages are, digital zakat will help the state to collect zakat from all eligible Muslims and all types of Zakatable wealth and redistribute it fairly and equatibly to recipients thereby, creating a just society for all (Mohsin, 2021).

\section{Method}

This study uses a quantitative approach because the results of the research are measurable. What is measured from this research is the digital transformation value of zakat institutions on the island of Kalimantan. The data from this study were taken from two parts, namely primary data. Primary data was obtained from filling out questionnaires distributed through google forms which were then processed into data. The population in this study were all zakat institutions in Kalimantan which consisted of 5 provinces, namely East Kalimantan, West Kalimantan, Central Kalimantan, North Kalimantan, and South Kalimantan. While the determination of the sample is based on cluster sampling. This study uses descriptive quantitative analysis techniques. Considering that research instruments are vulnerable to 


\section{$A \mathrm{IC} \quad$ Annual International Conference \\ on Islamic Economics and Business, 2021}

respondents' perceptions, further research with a qualitative approach is needed to strengthen the conclusions.

This online questionaire item consists of statements for each indicator of the digital divide level. Alternative answers consist of five choices in the form of a Likert scale which includes Strongly Agree (SS), Agree (S), Neutral (N), Disagree (TS), and Strongly Disagree (STS)(Sugiyono, 2016). Each alternative answer has a graded score of 5, 4, 3, 2, 1.

Tabel 2. Score categorization guide

\begin{tabular}{|c|c|}
\hline Category & Score Range \\
\hline Highhest & $37<=\mathrm{x}$ \\
\hline Medium & $26<=37$ \\
\hline Lowest & $26>\mathrm{x}$ \\
\hline
\end{tabular}

\section{Result and Discussion}

Dissemination of questionnaires via email, telephone number, and social networks. Researchers managed to collect a sample of 23 from 57 zakat institutions on the island of Kalimantan (Integrated Zakat Management Organization Supervision System, n.d.)

After the data was obtained by researchers from distributing questionnaires to respondents, the data was processed and analyzed using statistics and then presented in tabular form to answer the existing problem formulation.

Web-based zakat management can facilitate zakat management officers in terms of data input so as to minimize the occurrence of data redundancy in terms of inputting muzakki, mustahik and zakat receiving and sending data (Supriadi \& Fitriani, 2018). In addition, webbased zakat management can make it easier for officers to make reports on the receipt and distribution of zakat. Web-based zakat management can make it easier for zakat institutions to provide services to prospective muzakki. Zakat institutions that have maximized webbased zakat management are zakat institutions in Central Kalimantan Province, while the lowest is zakat institutions in North Kalimantan Province.

Management of zakat based on Android applications can usually be downloaded from the Play Store. The service features are the same as the website but this is an application. It's easier to access on a smartphone. This application can help someone in calculating zakat easily. In addition, this application can also assist someone in sending zakat to zakat management institutions, inputting the nominal amount of zakat, and confirming zakat transactions (Andiantoro et al., 2015). The zakat institutions that have utilized the highest android-based zakat collection are Central Kalimantan, while the lowest is East Kalimantan.

External platforms such as e-commerce can collaborate with zakat institutions. Ecommerce can provide facilities for muzakki in paying zakat, infaq, alms, and waqf (Ziswaf). Examples of e-commerce are Tokopedia, Blibli, Bukalapak, KasKus, MatahariMall, and Lazada. By collaborating with e-commerce, muzakki is directly reminded to pay ziswaf when shopping. The highest zakat institution that has utilized zakat collection by collaborating with e-commerce is South Kalimantan, while the lowest is Central Kalimantan.

E-Wallet is an external platform that offers many benefits to its users, for example the benefits of e-wallet are to provide ease of use, increase productivity, time efficiency, improve user performance and provide promotional offers. The highest zakat institutions that have utilized the external e-wallet platform are West Kalimantan, while the lowest are North Kalimantan and Central Kalimantan.

Collaboration with Kitabisa.com crowdfunding or with ride-hailing platforms such as Grab and Gojek can increase zakat collection. The highest zakat institutions that have utilized 


\section{$A \mathrm{IC} \overline{I E B}$ Annual International Conference \\ on Islamic Economics and Business, 2021}

crowdfunding and ride-hailing are South Kalimantan, while the lowest are North Kalimantan and Central Kalimantan.

Digitization of zakat management in the form of based muzakki service. With muzaki services based applications, everyone can access information in the application with data transparency. The highest zakat institution that has utilized application-based muzaki services is South Kalimantan, while the lowest is Central Kalimantan.

Internal platform where this platform is developed from the internal institutional side. The highest value of digital digital transformation on the internal platform indicators is Central Kalimantan, while the lowest is East Kalimantan.

Zakat that is integrated with the database system is a digitization system in distribution. Zakat institutions have mustahik identity data. The zakat institution that has the highest score is East Kalimantan, while the lowest is North Kalimantan. For more details can be seen from the following image :

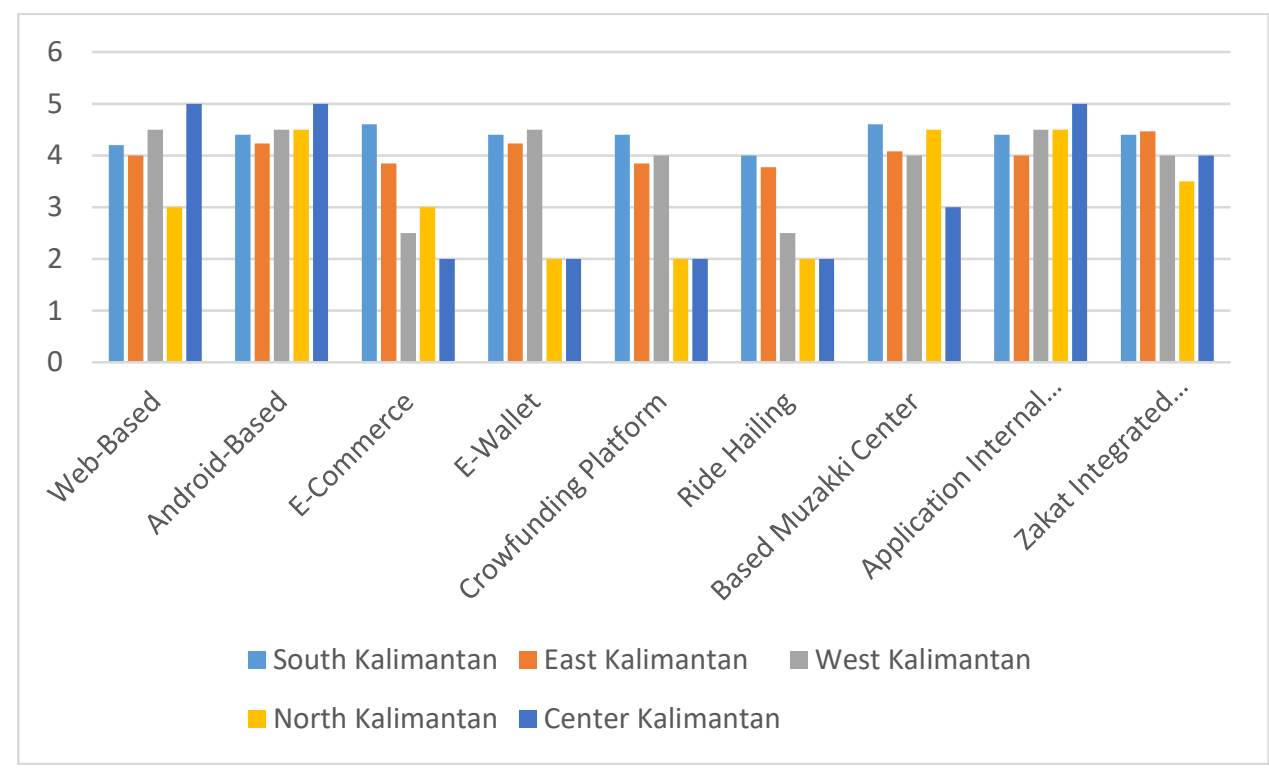

Fig. 2. Digital Management in each Province

Overall, the value of digital transformation in each province in Kalimantan can be illustrated as follows:

Table 3. Score Category

\begin{tabular}{|c|c|c|}
\hline Province & Digital Management & Category \\
\hline South Kalimantan & 3.89 & Medium \\
\hline East Kalimantan & 3.56 & Medium \\
\hline West Kalimantan & 3.44 & Medium \\
\hline North Kalimantan & 3.22 & Low \\
\hline Central Kalimantan & 3.44 & Medium \\
\hline
\end{tabular}

After the indicator is expressed in the form of an index, the value of the digital dividend index for each province is known. South Kalimantan Province is the reference province for digital dividend calculation because the average value of digital transformation is the highest. 


\section{$A I \overline{I E B}$ Annual International Conference \\ on Islamic Economics and Business, 2021}

The value of the digital divide index for each province in Kalimantan can be seen in the table. 3 and can be shown more clearly in the Figure 3.

From the table above, it can be seen that the largest digital divide index value is North Kalimantan. This is because the use of external platforms is the least compared to other provinces, such as the use of e-wallet, crowdfunding, ride-hailing, and e-commerce. Then below West Kalimantan and Central Kalimantan with the same digital dividend index value, East Kalimantan, and the lowest is South Kalimantan.

Table 4. Digital Divide

\begin{tabular}{|c|c|}
\hline Province & Digital Divide \\
\hline North Kalimantan & 0.67 \\
\hline Central Kalimantan & 0.45 \\
\hline West Kalimantan & 0.45 \\
\hline East Kalimantan & 0.33 \\
\hline South Kalimantan & 0 \\
\hline
\end{tabular}

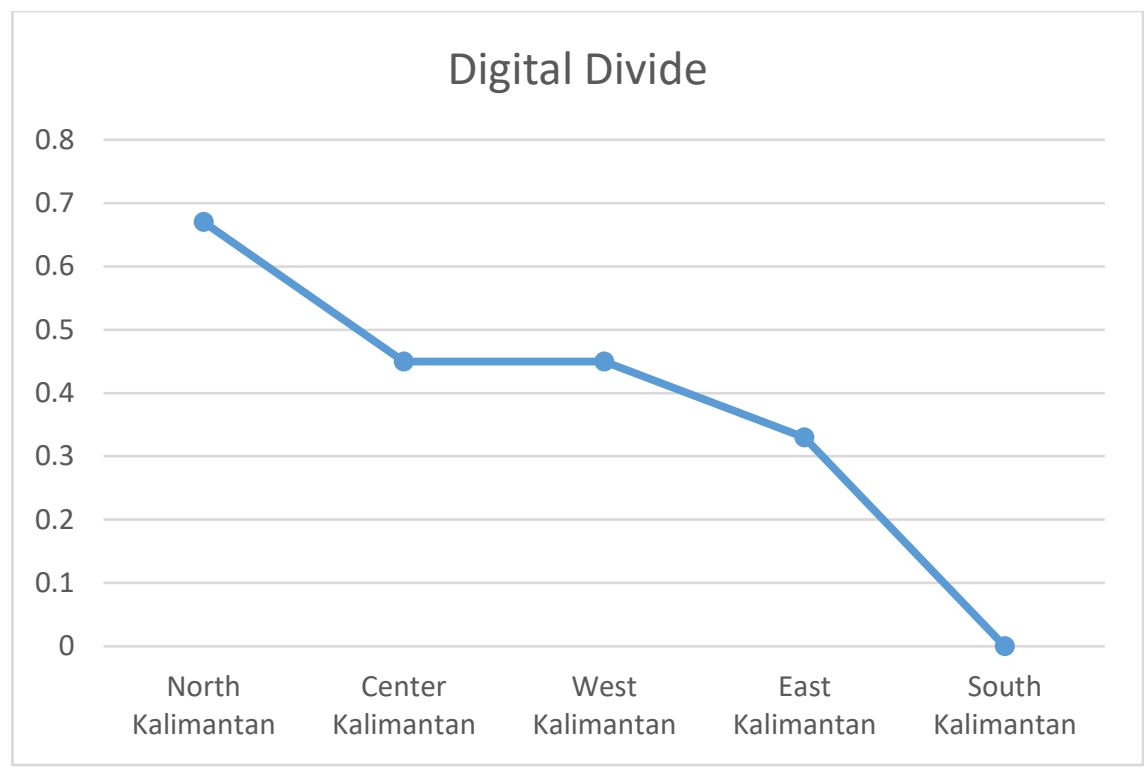

Fig. 3. Digital Divide

\section{Conclusion}

Based on the data obtained, it can be concluded that each zakat institution in each province, in general, has implemented zakat digitization. The province that is the best in digital transformation of zakat institutions is South Kalimantan. This is because the use of external platforms is the highest compared to other provinces, such as the use of e-wallet, crowdfunding, ride-hailing, and e-commerce. North Kalimantan has the largest digital divide index value. Meanwhile, the lowest digital divide value for South Kalimantan Province is East Kalimantan.

The results of this study can be used as consideration for both zakat institutions and related government agencies to improve zakat digitization. More than that, this research can 


\section{$A I C \overline{I E B} \quad$ Annual International Conference \\ on Islamic Economics and Business, 2021}

also be a reference to study digital transformation more deeply. Considering that research instruments are vulnerable to respondents' perceptions, a qualitative approach is needed to strengthen the conclusions.

\section{References}

Abodunrin, O., Oloye, G., \& Adesola, B. (2020). Coronavirus pandemic and its implication on global economy. International Journal of Arts, Languages and Business Studies, 4.

Aini, Z. N., Yuli, S. B. C., \& Hakim, R. (2018). Perilaku Muzakki dalam Membayar Zakat Melalui Transaksi Non-Tunai di Lembaga Inisiatif Zakat Indonesia (IZI) Surabaya. IQTISHODIA, Vol. 3, No. 1.

Andiantoro, Y., Sari, S. K., \& Ramadhani, K. N. (2015). Aplikasi Zakat Berbasis Android. EProceedings of Applied Science, 1(3).

Ariyanti, S. (2016). Studi pengukuran digital divide di Indonesia. Buletin Pos Dan Telekomunikasi, 11(4), 281-292.

B. Hinings, T. Gegenhuber, \& R. Greenwood. (2018). Digital innovation and transformation: An institutional perspective. Inf. Organ, 28, no. 1, pp. 52-61,.

Bartik, A. W., Bertrand, M., Cullen, Z., Glaeser, E. L., Luca, M., \& Stanton, C. (2020). The impact of COVID-19 on small business outcomes and expectations. Proceedings of the National Academy of Sciences, 117(30), 17656-17666.

Basrowi, B., \& Utami, P. (2020). Pemanfaatan Teknologi Dalam Peningkatan Penerimaan Zakat, Jumlah Muzaki, Dan Pengurangan Resiko Zakat. Al-Urban: Jurnal Ekonomi Syariah Dan Filantropi Islam, 4(1), 101-114.

BRSbrsInd-20210818114849 (1).pdf. (n.d.).

Fadhilah, N. (2020). Strategi Manajemen Distribusi Islam Dalam Mengatasi Krisis Ekonomi Akibat Pandemi Covid-19. Business Innovation and Entrepreneurship Journal, 2(4), 242-251.

K. Osmundsen, J. Iden, \& B. Bygstad. (2018). Digital Transformation: Drivers, Success Factors, and Implications. Mediterr. Conf. Inf. Syst. Proc, 12, pp. 1-15.

Katon, F., \& Yuniati, U. (2020). Fenomena Cashless Society Dalam Pandemi Covid-19 (Kajian Interaksi Simbolik Pada Generasi Milenial). Jurnal SignaL, 8(2), 134-145.

Krismawintari, N. P. D., Komalasari, Y., \& Utama, I. (2020). Decision Model of Use EMoney in Covid-19 Pandemic Situation. Technium Soc. Sci. J., 10, 280.

Matt, C., Hess, T., \& Benlian, A. (2015). Digital transformation strategies. Business \& Information Systems Engineering, 57(5), 339-343.

Mohsin, M. I. A. (2021). The importance of state managing zakat through digitalization.

Ninglasari, S. Y., \& Muhammad, M. (2021). Zakat Digitalization: Effectiveness of Zakat Management in the Covid-19 Pandemic Era. Journal of Islamic Economic Laws, 4(1).

Putri, R. K., Sari, R. I., Wahyuningsih, R., Meikhati, E., \& Aji, A. W. (2021). Efek Pandemi Covid 19: Dampak Lonjakan Angka PHK Terhadap Penurunan Perekonomian Di Indonesia. Jurnal Bisnis Manajemen Dan Akuntansi (BISMAK), 1(2), 72-77.

Robin, R. (2021). Death Infectious: Impact of the Coronavirus Disease (COVID-19) on Stock Returns. Journal of Economics, Business, \& Accountancy Ventura, 24(1), 95-104.

S. Eaves J. Loonam, V. Kumar, \& G. Parry. (2018). Towards digital transformation: Lessons learned from traditional organizations. Strateg. Chang., 27, no. 2, pp. 101-109.

Santoso, I. R. (2019). Strategy for optimizing zakat digitalization in alleviation poverty in the era of industrial revolution 4.0. IKONOMIKA, 4(1), 35-52.

Sugiyono. (2016). Metode Penelitian Kuantitatif, Kualitatif, R\&D (Cet. 23). Alfabeta.

Supriadi, D., \& Fitriani, L. (2018). Perancangan sistem informasi zakat berbasis web. IJCIT (Indonesian Journal on Computer and Information Technology), 3(1). 


\section{$A I C \overline{I E B}$ Annual International Conference \\ on Islamic Economics and Business, 2021}

Susilawati, S., Falefi, R., \& Purwoko, A. (2020). Impact of COVID-19's Pandemic on the Economy of Indonesia. Budapest International Research and Critics Institute (BIRCIJournal): Humanities and Social Sciences, 3(2), 1147-1156.

Tiwari, S., Kumar, S., \& Guleria, K. (2020). Outbreak trends of coronavirus disease-2019 in India: A prediction. Disaster Medicine and Public Health Preparedness, 14(5), e33e38.

Utami, P., Suryanto, T., Nasor, M., \& Ghofur, R. A. (2020). The effect digitalization zakat payment against potential of zakat acceptance in national Amil zakat agency. Iqtishadia, 13(2), 216.

Van Dijk, J., \& Hacker, K. (2003). The digital divide as a complex and dynamic phenomenon. The Information Society, 19(4), 315-326.

Zubaidah, S., \& Afifah, A. (2020). Development of Zakat Management Digitalization in Indonesia. International Conference of Zakat, 459-468. https://doi.org/10.37706/iconz.2020.227 